\title{
In vitro antioxidant, antimicrobial and cytotoxic activities and green biosynthesis of silver \& gold nanoparticles using Callistemon citrinus leaf extract
}

\author{
Amal M. Saad ${ }^{1}$, Abdel-Aleem H. Abdel-Aleem ${ }^{2}$, Mosad A. Ghareeb $^{1}{ }^{*}$, Manal M. Hamed $^{1}$, \\ Mohamed S. Abdel-Aziz ${ }^{3}$, Asmaa H. Hadad ${ }^{1}$ \\ ${ }^{1}$ Medicinal Chemistry Department, Theodor Bilharz Research Institute, Giza 12411, Egypt. \\ ${ }^{2}$ Department of Organic Chemistry, Faculty of Science, Menoufia University, Shebin El-Kom, Egypt. \\ ${ }^{3}$ Microbial Chemistry Department, Genetic Engineering and Biotechnology Division, National Research Center, El-Bohouth Street 33, Dokki-Giza, Egypt.
}

\section{ARTICLE INFO}

Article history:

Received on: 12/09/2016

Accepted on: 28/01/2017

Available online: 30/06/2017

\section{Key words:}

Callistemon citrinus (L.); antioxidant; antimicrobial; cytotoxic;TPC; AgNPs; AuNPs; UV-vis; TEM, XRD.

\begin{abstract}
The current study was aimed to synthesis and characterization of silver (AgNPs) \& gold (AuNPs) nanoparticles using Callistemon citrinus leaf extract, and to evaluate their in vitro antioxidant, antimicrobial and cytotoxic activities as well as their total phenolic content (TPC). Silver and gold nanoparticles were synthesized and characterized via UV-vis absorbance spectroscopy, transmission electron microscopy (TEM), and X-ray diffraction (XRD) analyses. The antioxidant activity was evaluated using dot-blot and DPPH staining, and via phosphomolybdenum assays. Also, the in vitro antimicrobial activity was evaluated via disc agar plate method. The cytotoxic activity was evaluated via brine shrimp lethality test (BSLT), and TPC was estimated via FolinCiocalteu's assay. The transmission electron microscopy (TEM) analysis showed that the sizes of the synthesized AgNps were ranged from 8 to $14 \mathrm{~nm}$ with maximum UV/vis absorbance at $450 \mathrm{~nm}$. Also, the synthesized AuNPs exhibited an average size of 5.8 to $8.84 \mathrm{~nm}$ with maximum UV/vis absorbance at $535 \mathrm{~nm}$. Moreover, the results revealed that TPC of the tested extracts was ranged from 548.85 to $123.30 \mathrm{mg}$ gallic acid equivalent (GAE)/g dry extract. The total antioxidant capacity (TAC) was ranged from 643.90 to $147.96 \mathrm{mg}$ ascorbic acid equivalent/g dry extract. Furthermore, there is a promising antimicrobial activity against four strains with inhibition zones were ranged from 8.5 to $15.5 \mathrm{~mm}$, Penicillin $\mathrm{G}$ was used as positive control at concentration of $100 \mu \mathrm{g} / \mathrm{disc}$. In terms of $\mathrm{LC}_{50}$ the $n$-butanol extract $(63.09 \mu \mathrm{g} / \mathrm{ml})$ was the most potent cytotoxic, followed by EtOAc $(100.0 \mu \mathrm{g} / \mathrm{ml})$. In, conclusion the leaves of Callistemon citrinus showed a noticeable antioxidant, antimicrobial \& cytotoxic activities and the ability to produce AgNPs and AuNPs.
\end{abstract}

\section{INTRODUCTION}

Nanotechnology is an interesting field concerned by the green biosynthesis of nanoparticles (Mc Donell et al., 1999; Govindaraju and Tamilselvan, 2010). The green biosynthesis of metal nanoparticles using medicinal plants extracts is a vital issue of research due to their importance in the different fields especially drug delivery (Chaudhuri et al., 2016).

\footnotetext{
* Corresponding Author

Mosad A. Ghareeb, Medicinal Chemistry Department, Theodor Bilharz Research Institute, Giza 12411, Egypt. Email: m.ghareeb @ tbri.gov.eg
}

Numerous reports are available on the use of medicinal plants in the green biosynthesis of nanoparticles especially silver AgNPs and gold AuNPs. Moreover, most plants usually contain polyphenolic secondary metabolites viz., phenolic acids, flavonoids, and anthraquinones which act as strong reducing agents useful in the synthesis of nanoparticles (Siemieniec and Kruk, 2013). During the biosynthesis of silver and gold nanoparticles such polyphenolic compounds undergo keto-enol form conversion, which led to the reduction of $\mathrm{AuCl}_{4}^{-}$ion to $\mathrm{Au}^{0}$ metal, and similarly the conversion of $\mathrm{Ag}^{+}$ion to $\mathrm{Ag}^{0}$ metal (Siemieniec and Kruk, 2013; Abdel-Aziz et al., 2014). 
Callistemon is a genus of 34 species of shrubs in the family of Myrtaceae, all of which are endemic to Australia. It is sometimes considered as synonym of Melaleuca (Goyal et al., 2012; Simonet al., 2014). Phytochemical studies of different callistemon species revealed the presence of different monoterpenes, sesquiterpenes flavonoids (Chowdhury et al., 2012; Haque et al., 2013). Moreover, phytochemical explorations of members of this genus resulted in the identification of C-methyl flavonoids, triterpenoids, and phloroglucinol derivatives (Varma and Parthasarathy, 1975; Huq and Misra, 1997; Wollenweber et al., 2000). Callistemon citrinus (Family Myrtaceae) known as the bottle brush is an ornamental tree (Ali et al., 2011). It is native to South-Eastern Australia, and spread throughout the world as an ornamental plant in countries with mild climates (Haque et al., 2012). The plant was reported to possess antioxidant Jamzad et al., 2014), antimicrobial (Cock, 2012; Blesson et al., 2014), and cytotoxic activities (Ali et al., 2011).Therefore, the aims of this study were to use the leaves of Callistemon citrinus for the biosynthesis of silver (AgNPs) and gold (AuNPs) nanoparticles and to evaluate the antioxidant, cytotoxic, and antimicrobial activities of different fractions of Callistemon citrinus growing in Egypt.

\section{MATERIALS AND METHODS}

\section{Plant Materials}

Leaves of Callistemon citrinus L. (Family Myrtaceae) were collected from Zoo Garden, Giza, Egypt in May 2014. The plant was identified by Dr. Threase Labib Consultant of Plant Taxonomy at the Ministry of Agriculture; formerly the Head of Taxonomist Specialists-El-Orman Botanical Garden, Giza, Egypt, a voucher specimen (No.C1/4/1) was kept at the herbarium of the garden.

\section{Chemicals and Equipments}

All solvents and reagents used were of analytical grade. 2,2'-diphenyl-1-picraylhydrazyl (DPPH) free radical, and FolinCiocalteu's reagent (FCR) was purchased from (Sigma-Aldrich Co.). Gold chloride $\left(\mathrm{AuCl}_{3}\right)$, silver nitrate $\left(\mathrm{AgNO}_{3}\right)$, sodium carbonate, sodium phosphate, ammonium molybdate, ascorbic acid, and gallic acid were purchased from (Merck Chemical Co.). Thin layer chromatography (TLC) was performed over pre-coated silica plates (GF254, Merck). The absorbance measurements for the total phenolic content and antioxidant activity were recorded using the UV-Vis spectrophotometer Spectronic 601 (Milton Roy, USA).

\section{Extraction and Fractionation}

The dry powdered leaves of Callistemon citrinus (150 g), were soaked in $(1500 \mathrm{ml})$ of $85 \%$ methanol for one week at room temperature with shaking day by day followed by filtration and again extraction for four times. The organic solvent was removed in vacuo using rotatory evaporator. The $85 \%$ methanolic crude extract $(50 \mathrm{~g})$ was defatted by washing several times with petroleum ether $\left(60-80{ }^{\circ} \mathrm{C}\right)$. Forty five grams of the defatted methanol extract was undergoes fractionation using organic solvents i.e., $\mathrm{CH}_{2} \mathrm{Cl}_{2}$, EtOAc, and n-BuOH (3 x $100 \mathrm{ml}$ for each solvent). The yield of each fraction was determined and kept in dark for further analysis.

\section{Determination of Total Phenolic Content (TPC)}

The total phenolic content was determined using FolinCiocalteu's reagent according to the reported methods (Kumaret al., 2008; El-Sayed et al., 2009).

\section{Antioxidant Assays \\ Rapid Screening of Antioxidant by Dot-blot and DPPH Staining}

The antioxidant by dot-blot and DPPH staining was qualitatively estimated according to reported method (Ghareeb et al., 2014; Shoeb et al., 2014).

\section{Determination of Total Antioxidant Capacity (TAC)}

The antioxidant activity was determined according to phosphomolybdenum assay (El-Sayed et al., 2010; Ghareeb et al., 2013).

\section{Antimicrobial Activity}

The antimicrobial activity was evaluated via disc agar plate method according to the reported method (Bauer et al., 1966; Ghareeb et al., 2015a).

\section{Cytotoxic Activity Using Brine Shrimp Lethality Test (BSLT)}

The preliminary cytotoxic activity of all tested extracts of C. citrinus was evaluated according to the reported procedure (Ipsen and Feigi, 1970; Ghareeb et al., 2015b).

\section{Preparation of Plant Leaf Extract for Biosynthesis of Nanoparticles}

The fresh green leaves of $C$. citrinus were thoroughly washed with distilled water to remove of any odd materials especially soil and dust. Twenty gram of clean leaves were boiled in $50 \mathrm{ml}$ distilled water in Erlenmeyer flask of 500-ml volume for $30 \mathrm{~min}$ and the leaf debris were removed by filtration through Whatman filter paper (No. 1), the extract was evaporated up to 25ml (Abdel-Aziz et al., 2014).

\section{Biosynthesis of Silver Nanoparticles (AgNPs)}

Fifty milliliter of $5 \mathrm{mM}$ silver nitrate solution $\left(\mathrm{AgNO}_{3}\right)$ were prepared in stopper conical flask and $0.25 \mathrm{ml}$ of the formerly prepared $C$. citrinus leaf extract were added and left at room temperature for $12 \mathrm{~h}$ and the produced reddish brown colour indicate the biosynthesis of silver nanoparticles (AgNPs) (AbdelAziz et al., 2014).

\section{Biosynthesis of Gold Nanoparticles (AuNPs)}

Fifty milliliter of $5 \mathrm{mM}$ gold chloride solution $\left(\mathrm{HAuCl} .3 \mathrm{H}_{2} \mathrm{O}\right)$ were prepared in stopper conical flask and $0.5 \mathrm{ml}$ of 
the previously prepared $C$. citrinusleaf extract were added and left at room temperature for $12 \mathrm{~h}$ and the produced purple- reddish colour indicate the biosynthesis of gold nanoparticles (AuNPs)(Abdel-Aziz et al., 2014).

\section{Characterization of AgNPs and AuNPs Nanoparticles UV-vis Absorbance Spectroscopy Analysis}

The bio-reduction of silver nitrate $\left(\mathrm{AgNO}_{3}\right)$ to AgNPs and gold chloride to AuNPs was monitored periodically by UV-vis spectroscopy (Shimazu2401PC) after dilution of the samples with deionized water (Rautet al., 2009). A UV-vis spectrograph of AgNPs and AuNPs was recorded by using a quartz cuvette with water as reference. The UV-vis spectrometric readings were recorded at a scanning speed of 190-900 nm (Leela and Vivekanandan, 2008).

\section{TEM Analysis}

The suspensions containing AgNPs and AuNPs synthesized by $C$. citrinus leaf extract were sampled by TEM analysis using JEOL model 1200 EX electron microscope. TEM samples were prepared by placing a drop of the suspension of AgNP or AuNPs solutions on carbon-coated copper grids and allowing water to evaporate. The samples on the grids were allowed to dry for $4 \mathrm{~min}$. The shape and size of nanoparticles from C. citrinus were determined from TEM micrographs (Elavazhagan and Arunachalam, 2011).

\section{X-ray Diffraction (XRD)}

Measurements XRD of the C. citrinusreduced silver nanoparticles or gold nanoparticles were carried out on dropcoated films of the respective solutions onto glass substrates by a Phillips PW 1830 instrument operating at a voltage of $40 \mathrm{kV}$ with $\mathrm{Cu} \mathrm{Kx}$ radiation(Abdel-Aziz et al., 2014).

\section{Statistical Analysis}

All data were presented as mean \pm S.D. of triplicates $(n=3)$ according to Annegowda et al. 2010 using SPSS 13.0 program (SPSS Inc. USA) (Annegowda et al., 2010).

\section{RESULTS AND DISCUSSION}

\section{Total Phenolic Content (TPC)}

In the Folin-Ciocalteu's assay, the $n-\mathrm{BuOH}$ extract was found to be the most polyphenolic enriched extract of TPC (537.65 mg GAE/g dry extract) compared to that of EtOAc, defatted $85 \%$ $\mathrm{MeOH}$, and aqueous extracts $(442.20,411.11,315.50 \mathrm{mg}$ GAE/g dry extract, respectively), however the rest of tested extracts showed low content of phenolic compounds 117.80 and $67.75 \mathrm{mg}$ GAE/g dry extract for $\mathrm{CH}_{2} \mathrm{Cl}_{2}$ and pet. ether, respectively (Table $1)$.

Moreover, limited data is available on the previous investigations on the TPC of different parts of $C$. citrinus. Abdelhady et al. (2011) reported that the total phenolic content of
$80 \%$ ethanolic extracts from leaves of three Callistemon species, namely $C$. lanceolatus, $C$. comboynensis, and $C$. viridiflorous was 104, 95.8, and $79 \mathrm{mg} \mathrm{g}^{-1}$, respectively (Abdelhady et al., 2011).

Table 1: Total extractable content, total phenolic content, and total antioxidant capacity of defatted $85 \%$ methanolic extract of $C$. citrinus as well as its subfractions.

\begin{tabular}{|c|c|c|c|}
\hline Sample & 흘 & $\begin{array}{c}\text { Total phenolic } \\
\text { (mg gallic acid } \\
\text { equivalent/g } \\
\text { extract) }^{2}\end{array}$ & $\begin{array}{c}\text { Total antioxidant } \\
\text { capacity } \\
\text { (mg AAE /g ext.) }^{3}\end{array}$ \\
\hline Defatted $85 \% \mathrm{MeOH}$ & 20.55 & $411.11 \pm 1.24$ & $492.67 \pm 1.55$ \\
\hline Pet. ether & 2.62 & $67.75 \pm 1.32$ & $110.56 \pm 0.85$ \\
\hline $\mathrm{CH}_{2} \mathrm{Cl}_{2}$ & 3.68 & $117.80 \pm 1.56$ & $175.58 \pm 0.90$ \\
\hline EtOAc & 1.44 & $442.20 \pm 0.98$ & $510.56 \pm 1.15$ \\
\hline$n$-BuOH & 2.04 & $537.65 \pm 1.30$ & $804.87 \pm 1.20$ \\
\hline $\mathrm{H}_{2} \mathrm{O}$ & 1.54 & $315.50 \pm 0.68$ & $252.02 \pm 0.75$ \\
\hline
\end{tabular}

Results are expressed as mean values \pm standard deviation $(n=3)$

${ }^{\mathbf{1}}$ TEC (total extractable content).

${ }^{2} \mathrm{TPC}$ (total phenolic content) values are expressed as $\mathrm{mg}$ gallic acid equivalent/g extract (mg GAE/g ext.).

${ }^{3}$ Total antioxidant capacity values are expressed as $\mathrm{mg}$ ascorbic acid equivalent/g extract (mg AAE/g ext.).

\section{Antioxidant Activities}

The antioxidant activity of different parts of $C$. citrinusis well known (Jamzad et al., 2014; Puranik et al., 2014). The qualitative antioxdant results revealed that most tested fractions showed promising activity which was confirmed via the appearance of white zones upon the dark purple background. Among them, the $n-\mathrm{BuOH}$ fraction showed the potent activity followed by the defatted $85 \% \mathrm{MeOH}, 85 \% \mathrm{MeOH}$, EtOAc, and $\mathrm{H}_{2} \mathrm{O}$ in comparison of two standards quercetin and ascorbic acid (Figure 1).

$85 \% \mathrm{MeOH}$
Defatted $85 \% \mathrm{MeOH}$
Pet. ether
$\mathrm{CH}_{2} \mathrm{Cl}_{2}$
EtOAc
$n$-BuOH
$\mathrm{H}_{2} \mathrm{O}$
Flower $85 \% \mathrm{MeOH}$
Quercetin
Ascorbic acid
mg $/ \mathrm{ml}$

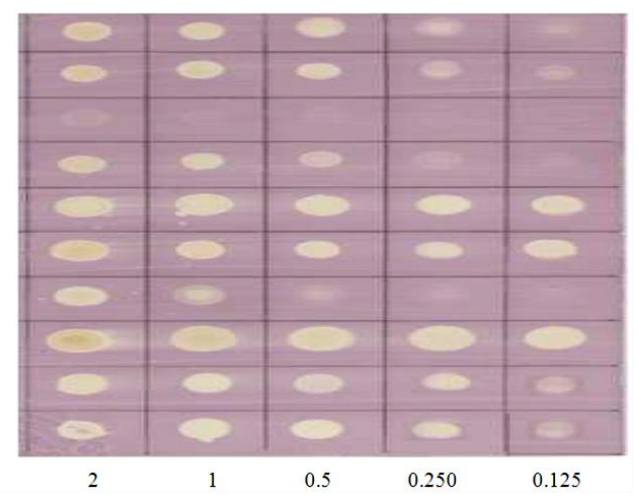

Fig. 1: Dot-blot qualitative antioxidant assay of different fractions of $C$ citrinus on silica sheet stained with DPPH solution in methanol.

Furthermore, in the phosphomolybdenum assaythe $n$ BuOHextract was the most potent antioxidant of TAC (804.87 \pm $1.20 \mathrm{mg}$ ascorbic acid equivalent/g dry extract), followed by ethyl acetate, defatted $85 \% \mathrm{MeOH}$, aqueous extracts of TAC (510.56 \pm $1.15,492.67 \pm 1.55,252.02 \pm 0.75$, respectively), however the weak activity was recorded with the remaining fractions $\mathrm{CH}_{2} \mathrm{Cl}_{2}$ $(175.58 \pm 0.90)$, and pet. ether $(110.56 \pm 0.85) \mathrm{mg}$ ascorbic acid equivalent/g dry extract)(Table 1). Puranik et al. (2014) reported that the antioxidant activity of the ethanol extract of $C$. citrinus 
flower was assessed via DPPH assay, which showed an inhibition of free radical at a percentage of $56.04 \pm 0.6$ at lowest concentration $25 \mu \mathrm{g} / \mathrm{ml}$, and $89.75 \pm 0.8$ at highest concentration $400 \mu \mathrm{g} / \mathrm{ml}$ (Puranik et al., 2014). Also, Jamzad et al. (2014) have been investigated the antioxidant activity of the $80 \%$ methanol extract from the flowers, leaves and stems of $C$. citrinus using DPPH antioxidant assay, the highest antioxidant activity was observed for flowers (inhibition $\%=93.32 \%$ ), followed by leaves (inhibition $\%=64.11 \%$ ), and stems (inhibition $\%=44.17 \%$ ) (Jamzad et al., 2014).

\section{In Vitro Antimicrobial Activity}

The different extracts of $C$. citrinus were tested for their in vitro antimicrobial activity against five pathogenic microbial strains including Gram +ve and Gram -ve bacteria and fungi i.e., Pseudomonas aeruginosa with inhibition zones ranged from 18.0 to $7.5 \mathrm{~mm}$, Staphylococcus aureus with inhibition zones ranged from 17.5 to $7.5 \mathrm{~mm}$, Methicillin-resistant Staphylococcus aureus with inhibition zones ranged from 18.5 to $7.5 \mathrm{~mm}$,Candida albicans with inhibition zones ranged from 21.5 to $8.5 \mathrm{~mm}$,however85\% $\mathrm{MeOH}$ of flower part only showed a moderate activity against Aspergillus niger with inhibition zone $9.5 \mathrm{~mm}$ (Table 2). Blesson et al. (2014) reported on the antibacterial activity of the ethanolic leafextractof $C$. citrinus against Staphylococcus aureus, and the results revealed that it showed a significant antibacterial activity with inhibition zone diameter of $40 \mathrm{~mm}$ (Blesson et al., 2014). The ethyl acetate and petroleum ether extracts of the stem bark of $C$. citrinus were subjected to screening for antimicrobial activity, these extracts showed moderate antimicrobial activity (9-10.5 mm) against Gram positive bacteria i.e., Bacillus subtilis, B. cereus, B. megaterium \& Staphylococcus aureus, (9-11 mm), and against Gram negative bacteria i.e., Vibrio parahaemolyticus, V. minicus, Echerichea coli, Salmonella typhi, S. para typhi, Shigella boydii, Sh. Dysenteriae, Pseudomonus sp., (9-10.5 mm), and against fungi i.e.,Candida albicans \& Aspergilus niger at $300 \mu \mathrm{g} / \mathrm{disc}$ in comparison with kanamycin at $30 \mu \mathrm{g} / \mathrm{disc}$ (Haque et al., 2012). The antimicrobial activity of the methanolic extract of $C$. citrinus leaf $\&$ flower was investigated against a panel of bacteria and fungi. The results revealed thatthe tested leaf extracts inhibited the growth of $43 \%$ and flower extracts inhibited the growth of $64 \%$ of the bacteria tested, respectively. Gram-positive bacteria (100\% inhibited) were more susceptible to $C$. citrinus extracts than were
Gram-negative bacteria (27\% inhibited by leaf extracts; $55 \%$ inhibited by flower extracts) (Cock, 2012). Furthermore, the chloroform, ethanol, and aqueous extracts form the leaves of $C$. citrinus were subjected to screening their antimicrobial activities against Gram(+)ve and Gram(-) microorganisms i.e., Bacillus subtilis, Bacillus pumilis and Escherichia coli, the chloroform extract exhibited moderate to significant activity against all the tested microbial strains, and the alcoholic extract exhibited moderate activity (Krishna et al., 2012). The antibacterial potential of the petroleum ether, chloroform, and methanolic extracts of $C$. citrinus was examined against Bacillus subtilis, Escherichia coli, and Pseudomonas aeruginosa, all the tested extracts showed good activity against $P$. auregenosa $(12.3 \pm 0.44 ; 12.9 \pm 0.33 \& 23 \pm 0.33)$, E. coli $(11.3 \pm 0.00 ; 14.9 \pm 0.66 \& 20.21 \pm 0.33)$, and $B$. subtilis $(12 \pm 0.33 ; 15.5 \pm 0.33 \& 25.09 \pm 0.33$ at $100 \mathrm{mg} / \mathrm{ml})$ all respectively for petroleum ether, chloroform, and methanolic extracts, and there is no any activity was recorded against the fungal strains (Shinde et al., 2012).

These findings afford new outlooks for the use of the $C$. citrinus leaves as a good source of naturally occurring antimicrobial agents.

\section{Cytotoxic Activity via BSLT}

In the BSLT, different extracts of $C$. citrinus were tested as preliminary cytotoxic agent using Artemia salina Leach eggs (Meyer et al., 1982), and the results in (Table 3 and Figure 2) revealed that the $n-\mathrm{BuOH}$ extract was the strongest cytotoxic with $\mathrm{LC}_{50}=63.09 \mu \mathrm{g} / \mathrm{ml}$, followed by $85 \%$ methanol $\left(\mathrm{LC}_{50}=125.89\right)$, defatted $85 \%$ methanol $\left(\mathrm{LC}_{50}=158.48\right)$, EtOAc $\left(\mathrm{LC}_{50}=100.0\right)$, and $\mathrm{H}_{2} \mathrm{O} \quad\left(\mathrm{LC}_{50}=398.10\right) \mu \mathrm{g} / \mathrm{ml}$. On the other hand the lowest cytotoxic effect was recorded with $\mathrm{CH}_{2} \mathrm{Cl}_{2}\left(\mathrm{LC}_{50}=398.10\right)$, pet. ether $\left(\mathrm{LC}_{50}=501.18\right)$, compared with the $85 \%$ methanol of flower part $\left(\mathrm{LC}_{50}=79.43\right) \mu \mathrm{g} / \mathrm{ml}$. Ali et al. (2011) have been evaluated the brine shrimp cytotoxicity of fruits of $C$. citrinus, and the results revealed that the $\mathrm{EC}_{50}$ value was $65.5 \pm 7.28(60.8-69.4, n=4)$ $\mathrm{mg} / \mathrm{ml}$, which imply that the plant may be a source of cytotoxic agents and therefore, may be a source of anticancer constituents (Ali et al., 2011).

Furthermore, the petroleum ether, ethyl acetate, and methanol extracts of the stem bark of C.citrinus were subjected to screenings for BSLT, and the results revealed that the methanol extract showed potent cytotoxicity with $\mathrm{LC}_{50}$ value of $11.27 \mu \mathrm{g} / \mathrm{ml}$ (Haque et al., 2012).

Table 2: Antimicrobial activity of the defatted $85 \%$ methanolic extract of $C$. citrinus as well as its derived sub-fractions.

\begin{tabular}{|c|c|c|c|c|c|}
\hline \multirow[t]{2}{*}{ Sample } & \multicolumn{5}{|c|}{ Clear Inhibition zone $(\phi \mathrm{mm})$} \\
\hline & Staphylococcus aureus & MRSA & Pseudomonas aeruginosa & Candida albicans & Aspergillus niger \\
\hline $85 \% \mathrm{MeOH}$ & $14.5 \pm 0.70$ & $15.5 \pm 0.70$ & $16.5 \pm 0.70$ & $18.5 \pm 0.70$ & - \\
\hline Defatted $85 \% \mathrm{MeOH}$ & $8.5 \pm 0.70$ & $9.5 \pm 0.70$ & $13.5 \pm 0.70$ & $13.5 \pm 0.70$ & - \\
\hline Pet. ether & $17.5 \pm 0.70$ & $18.5 \pm 0.70$ & $18.0 \pm 1.41$ & $21.5 \pm 0.70$ & - \\
\hline $\mathrm{CH}_{2} \mathrm{Cl}_{2}$ & $10.5 \pm 0.70$ & $7.5 \pm 0.70$ & $9.5 \pm 0.70$ & $10.0 \pm 1.41$ & - \\
\hline EtOAc & $7.5 \pm 0.70$ & $8.5 \pm 0.70$ & $12.0 \pm 1.41$ & $14.5 \pm 0.70$ & - \\
\hline$n$-Butanol & $9.5 \pm 0.70$ & $10.5 \pm 0.70$ & $13.5 \pm 0.70$ & $12.0 \pm 1.41$ & - \\
\hline $\mathrm{H}_{2} \mathrm{O}$ & $8.5 \pm 0.70$ & $9.5 \pm 0.70$ & $7.5 \pm 0.70$ & $8.5 \pm 0.70$ & - \\
\hline $85 \% \mathrm{MeOH}$ Flower & $13.0 \pm 1.41$ & $10.5 \pm 0.70$ & $13.5 \pm 0.70$ & $14.0 \pm 1.41$ & $9.5 \pm 0.70$ \\
\hline Penicillin G & $27.5 \pm 0.85$ & $28 \pm 0.95$ & $20 \pm 1.15$ & $25 \pm 1.20$ & - \\
\hline
\end{tabular}

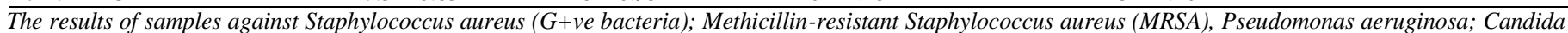
albicans (yeast); Aspergillus niger (fungus); (-); inactive. Penicillin G as positive control. 
Table 3: Cytotoxic activity of defatted $85 \%$ methanol extract of $C$. citrinus as well as its derived sub-fractions

\begin{tabular}{|c|c|c|}
\hline Sample & $\mathrm{LC}_{50 \pm}+\mathrm{SE}$ & (CI) \\
\hline $85 \%$ Methanol & $125.89 \pm 6.64$ & $(139.17-112.61)$ \\
\hline Defatted $85 \%$ Methanol & $158.48 \pm 5.24$ & $(168.96-148)$ \\
\hline Petroleum ether & $501.18 \pm 10.33$ & $(521.84-480.52)$ \\
\hline $\mathrm{CH}_{2} \mathrm{Cl}_{2}$ & $398.10 \pm 9.10$ & $(416.30-379.9)$ \\
\hline Ethyl acetate & $100.0 \pm 5.14$ & $(110.28-89.72)$ \\
\hline$n-\mathrm{BuOH}$ & $63.09 \pm 4.50$ & $(72.09-54.09)$ \\
\hline $\mathrm{H}_{2} \mathrm{O}$ & $398.10 \pm 8.52$ & $(415.14-381.06)$ \\
\hline $85 \%$ Methanol Flower & $79.43 \pm 5.11$ & $(89.65-69.21)$ \\
\hline
\end{tabular}

Means \pm standard error.

$95 \%$ confidence limits in parentheses.

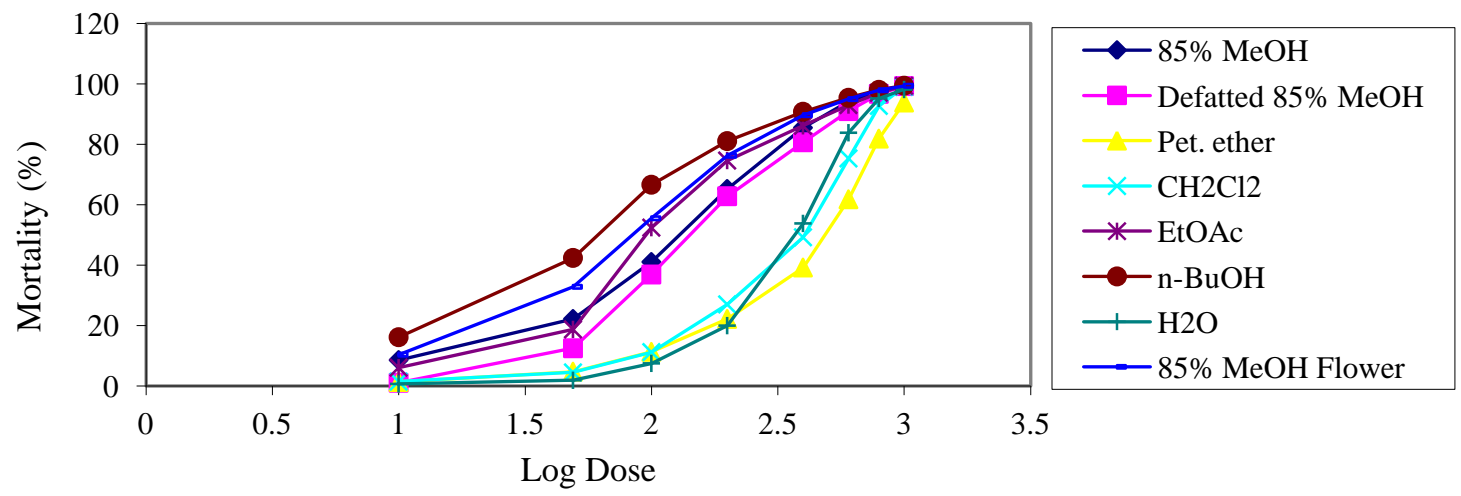

Fig. 2: Estimation of $\mathrm{LC}_{50}$ by plot of percent mortality of brine shrimp larvae against different dosage of different extracts of $C$. citrinus.

\section{Biosynthesis of Nanoparticles}

The chemical and physical techniques used in synthesis process of nanoparticles have some disadvantages including highly cost, highly energy consumption, and environmental risks. Therefore, scientists try to use alternative eco-friendly biological methods to overcome such disadvantages via using fungus, plant extracts, microorganisms, and enzymes (Willner et al., 2006; Jha et al., 2009; Mittal et al., 2013; Chaudhuri et al., 2016).

\section{Biosynthesis of Silver Nanoparticles (AgNPs)}

Silver, is a very common and well-known metal, has gained value due to its wide range of applications. Among the nanoparticles, silver nanoparticles have several vital applications especially in the biomedical field (Pal et al., 2007; Christopher et al.,2015). In the current study, when $C$. citrinus leaf extract was added to an aqueous solution of silver nitrate $(5 \mathrm{mM})$, the colour was changed to brownish colour due to the reduction of silver ions to metallic silver (Figure 3). By measuring the UV/vis absorbance of the produced solution, it has been found the appearance of peak at about $450 \mathrm{~nm}$ (Figure 4). Chaudhuri et al. (2016) reported the green synthesis of silver nanoparticles (AgNPs) using aqueous extract of Roheda (Tecomella undulata) at $60{ }^{\circ} \mathrm{C}$ and the colour was changed from pale yellow to light brownish colloidal solution, the UV-vis analysis of the synthesized nanoparticles were in the range of 410-450nm indicating the formation of AgNPs with particles size from $5.85 \mathrm{~nm}$ and $77.48 \mathrm{~nm}$, and atomic force microscopy indicated that height of the particle ranges from 3-18 nm (Chaudhuri et al., 2016).During the synthesis of silver nanoparticles using Annona reticulata the color of the reaction mixture, after $20 \mathrm{~min}$, at room temperature, changed to dark brown, indicating the formation of AgNPs (Sivakumar and Vidyasagar, 2014). Moreover, Ahmadet al. (2010) reported that the leaf extract of sacred basil was used to synthesize spherical silver nanoparticles (AgNPs) of a diameter of around $10 \mathrm{~nm}$ (Ahmad et al., 2010). Our results revealed that a change in colour has been achieved from colourless to yellowish brown to reddish brown to colloidal brown indicating AgNPs formation. The $\mathrm{UV} / \mathrm{vis}$ maximum of the produced AgNPs has been detected in the range 425 to $475 \mathrm{~nm}$ due to surface plasma resonance. Transmission electron microscopy was used to determine the microstructure of silver nanoparticles synthesized by using the leaf extract of $C$. citrinus and it has been found that AgNPs sizes of 8$14 \mathrm{~nm}$ were produced (Figure 5). Also, Figure 6 showing the characteristic peaks of metallic Ag located at $37.8^{\circ}, 43.3^{\circ}$ and $63.5^{\circ}$ corresponding to the crystallographic planes (lll 111$),\left(\begin{array}{lll}0 & 0 & 2\end{array}\right)$, and (l $\left.\begin{array}{lll}0 & 2 & 2\end{array}\right)$ of silver, respectively, establishes a characteristic of crystalline metallic Ag phase. Based on the line width of the peak from crystalline plane ( $\left.\begin{array}{lll}1 & 1 & 1\end{array}\right)$, crystallite sizes were found to be around $20 \mathrm{~nm}$ for Ag. Several investigations studied the XRD of the plant leaf extract biosynthesized AgNPs have been done to study the production of metallic silver (in nano state) and their purity (Rashidipourand Heydari, 2014; Roy et al., 2015). 


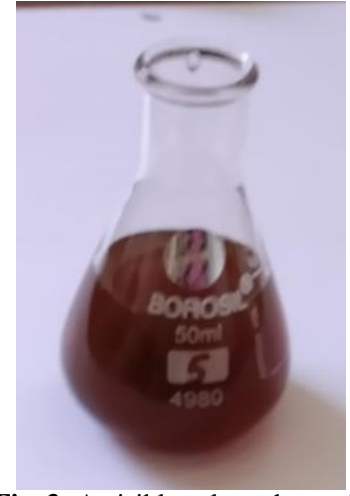

Fig. 3: A visible colour change in color during silver nanoparticle formation.

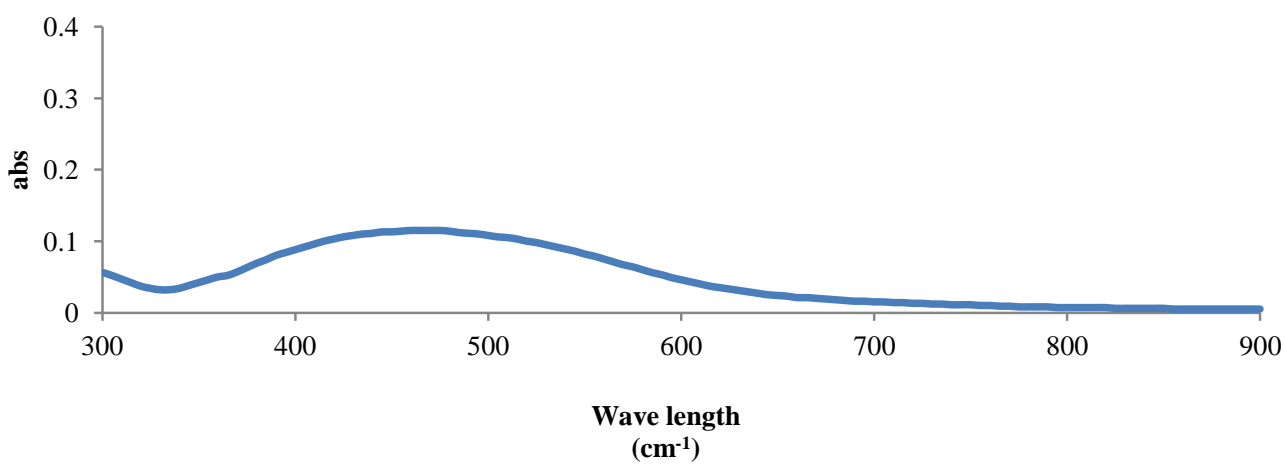

Fig. 4: UV-vis absorption spectrum of silver nanoparticles biosynthesized by $C$. citrinus leaf extract.

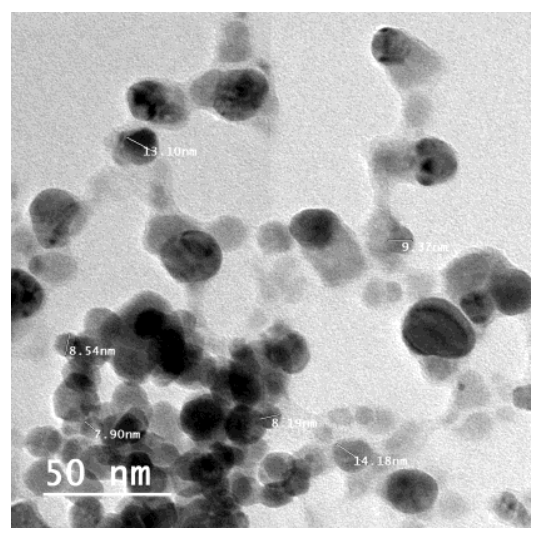

Fig 5: TEM micrographs of silver nanoparticles solution formed by incubation of $\mathrm{AgNO}_{3}$ solution containing C. citrinus leaf extract.

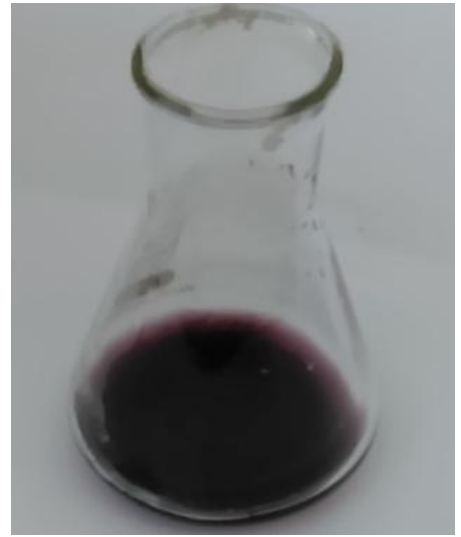

Fig. 7: A visible colour change in color during gold nanoparticle formation.

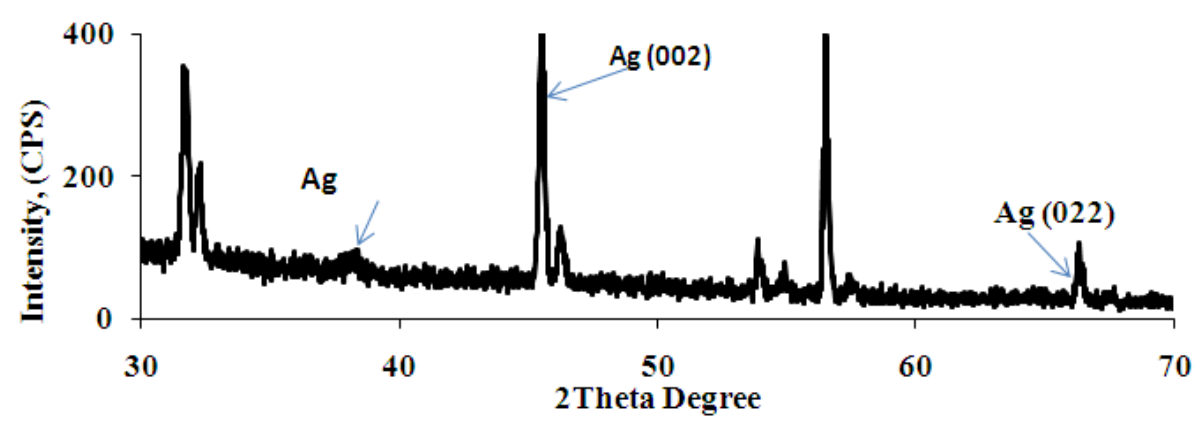

Fig. 6: X-ray diffraction (XRD) pattern of silver nanoparticles biosynthesized by C. citrinus leaf extract.

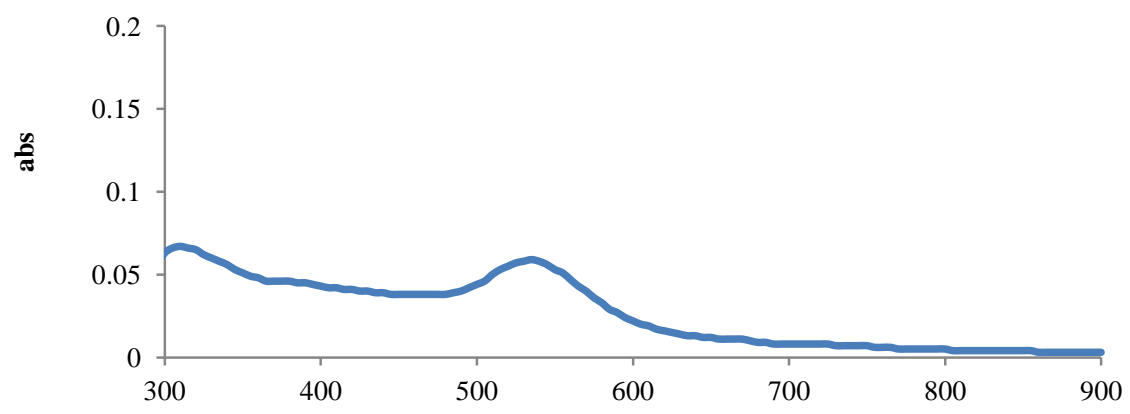

Wave length (cm-1)

Fig. 8: UV-vis absorption spectrum of gold nanoparticles biosynthesized by C. citrinus leaf extract. 


\section{Biosynthesis of GoldNanoparticles (AuNPs)}

In the current work, when $C$. citrinus leaf extract was added to gold salt $\left(\mathrm{HAuCl}_{4}\right)$, a change of colour form yellow to purple (violet) has been achieved due to the surface plasma resonance phenomenon (Figure7).

Spectrophotometric studies (UV/vis) revealed that the produced nanogold solution had maximum absorbance at $535 \mathrm{~nm}$ as measured by Shimadzu 2401PC (Figure 8). Eclipta prostate leaf extract was used for the biological synthesis of gold nanoparticles (AuNPs) and the produced AuNPs exhibited a ruby-red colour and had maximum spectral absorbance at 534nm (Rajakumar et al., 2016).Also, a violet color was originated as an evident of the formation of $\mathrm{Au}$ metal when $\mathrm{Au}$ ions were treated with Elettaria cardamonum (ELAICHI) aqueous extract (Pattayanak and Nayak, 2013).Our results also revealed that the formed AuNPs showed maximum absorbance at 540, 550 and $540 \mathrm{~nm}$ according to the ratio of $\mathrm{Au}$ solution and plant extract. Transmission electron microscopy (TEM) measurements of the synthesized AuNPs exhibited an average size of 5.8 to $8.84 \mathrm{~nm}$ (Figure 9). The structural properties of Au-NPs were investigated using the XRD technique. Figure 10 represented the Au NPs acquired in existence of $\mathrm{AuCl}_{4}$-analogous diffraction peaks are allocated to metallic $\mathrm{Au}$ phase with the characteristic peaks at $38.4^{\circ}, 44.5^{\circ}$ and $64.3^{\circ}$ attributed to the crystallographic planes ( $\left.\begin{array}{lll}1 & 1 & 1\end{array}\right),\left(\begin{array}{lll}2 & 0 & 0\end{array}\right)$ and $\left(\begin{array}{lll}2 & 2 & 0\end{array}\right)$, respectively. Several XRD studies have been done to determine the purity and presence of AuNPs (Ismail et al., 2014; Rao and Paria, 2014). Moreover, Chandran et al. (2006) reported that the leaf extract of Aloe vera was used in biosynthesis of triangular gold nanoparticles (AuNPs) (Chandran et al., 2006). Singh et al. (2012) reported the synthesis of gold nanoparticles using Cinnamomum camphora and Emblica officinalis leaves with particles size of 55-80 nm and 15-25 nm respectively with triangular and spherical shapes (Singh et al., 2012).

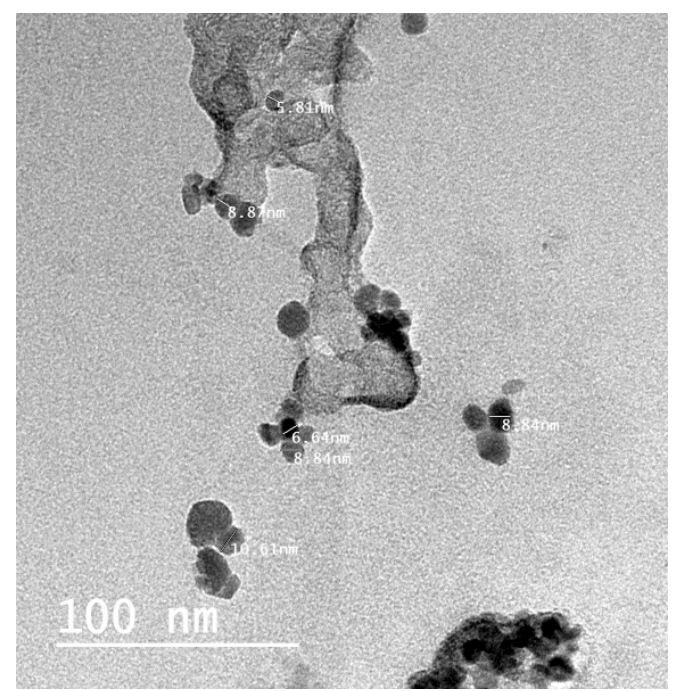

Fig. 9: TEM micrographs of gold nanoparticles solution formed by incubation of $\mathrm{HAuCl}_{4}$ solution containing C. citrinus leaf extract.

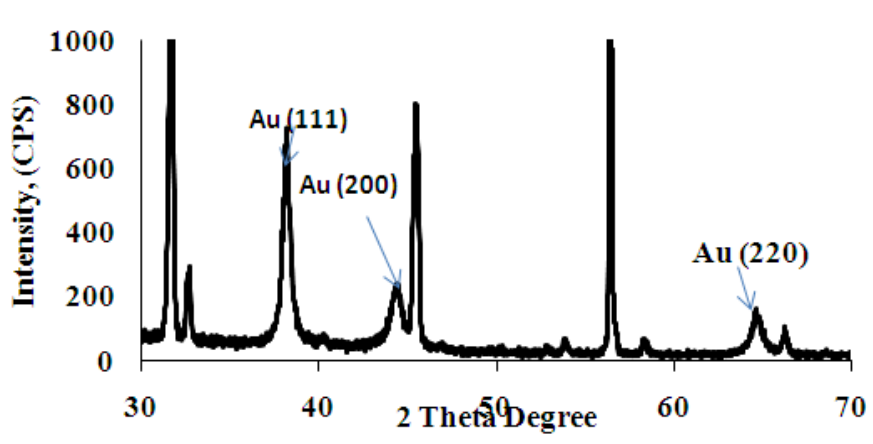

Fig. 10: X-ray diffraction (XRD) pattern of gold nanoparticles biosynthesized by $C$. citrinus leaf extract.

\section{CONCLUSION}

The current study revealed that silver and gold nanoparticles can be synthesized using $C$. citrinus leaves extract. The TEM analysis showed that the sizes of the synthesized AgNps and AuNPs were ranged from $8-14 \mathrm{~nm}$ and $5.8-8.84 \mathrm{~nm}$ respectively. Also, the most tested extracts of $C$. citrinus showed strong qualitative and quantitative antioxidant activities. Moreover, these fractions showed strong in vitro antimicrobial against four pathogenic microbial strains namely; Staphylococcus aureus, MRSA, Pseudomonas aeruginosa, and Candida albicans. Furthermore, the cytotoxic results showed $\mathrm{LC}_{50}$ values ranged from 63.09 to $501.18 \mu \mathrm{g} / \mathrm{ml}$. This finding provides an insight into the usage of the $C$. citrinus leaves as good source for the naturally occurring antioxidant, antimicrobial, and cytotoxic agents.

\section{ACKNOWLEDGMENT}

Authors wish to thank Dr. Threase Labib Consultant of Plant Taxonomy at the Ministry of Agriculture; formerly the Head of Taxonomist Specialists-El-Orman Botanical Garden, Giza, Egypt, for identification and authentication of the plant.

\section{Financial support and sponsorship: Nil.}

Conflict of Interests: There are no conflicts of interest.

\section{REFERENCES}

Abdel-Aziz MS, Shaheen MS, El-Nekeety AA, Abdel-Wahhab MA. Antioxidant and antibacterial activity of silver nanoparticles biosynthesized using Chenopodium murale leaf extract. J Saudi Chem Soc, $2014 ; 18,356-363$.

Abdelhady MIS, Motaal AA, Beerhues L. Total phenolic content and antioxidant activity of standardized extracts from leaves and cell cultures of three Callistemon species. Am J Plant Sci, 2011; 2: 847850 .

Ahmad N, Sharma S, Alam MK, Singh VN, Shamsi SF, Mehta BR, Fatma A. Rapid synthesis of silver nanoparticles using dried medicinal plant of basil. Colloids Surf B Biointerf, 2010; 81: 81.

Ali N, Ahmed G, Shah SWA, Shah I, Ghias M, Khan I. Acute toxicity, brine shrimp cytotoxicity and relaxant activity of fruits of Callistemon citrinus Curtis. BMC Complement Altern Med, 2011; 11(99): $1-8$.

Annegowda HV, Nee CW, Mordi MN, Ramanathan S, Mansor SM. Evaluation of phenolic content and antioxidant property of 
hydrolysed extracts of Terminalia catappa (L.) leaf. Asian J Plant Sci,2010; 9: 479-485.

Bauer AW, Kirby WM, Sherris JC, Trucks M. Antibiotic susceptibility testing by a standardized single disk method. Am J Clin Pathol, 1966; 45: 493-496.

Blesson J, Sebastian J, Chinju AR, Saji CV, Pillai DV, Manohar G, Jose J. South Indian plants Lawsonia inermis L., Ocimum sanctum L., Ficus religiosa L. and Callistemon citrinus L. exhibit antibiotic resistance modifying effect on native strain of Staphylococcus aureus. Int J Appl Sci Eng Res, 2014; 3(4): 869-878.

Chandran S., Chaudhary M., Pasricha R., Ahmad A., Synthesis of gold nanotriangles and silver nanoparticles using Aloe vera plant extract. Biotechnol. Progress, 2006; 22: 577.

Chaudhuri SK, Chandela S, Malodia L. Plant mediated green synthesis of silver nanoparticles using Tecomella undulata leaf extract and their characterization. Nano Biomed Eng,2016; 8(1): 1-8.

Chowdhury S, Ghosh AK, Maji S, Bala NN. Phytochemical screening and isolation of a pure phytoconstituent from the leaves of Callistemon salignus. Am J PharmTech Res, 2012; 2(3): 993-1000.

Christopher JG, Saswati B, Ezilrani P. Optimization of parameters for biosynthesis of silver nanoparticles using leaf extract of Aegle marmelos. Braz Arch Biol Technol. 2015; 58(5): 702-710.

Cock IE. Antimicrobial activity of Callistemon citrinus and Callistemon salignus methanolic extracts. Phcog Commn, 2012; 2(3): 5057.

Elavazhagan T, Arunachalam KD. Memecylon edule leaf extract mediated green synthesis of silver and gold nanoparticles. Int $\mathbf{J}$ Nanomed, 2011; 6: 1265-1278.

El-Sayed MM, Maher AM, Hanan AE, Sayed AE, Eman AE, Ghareeb MA. Bio-guided isolation and structure elucidation of antioxidant compounds from the leaves of Ficus sycomorus. Pharmacologyonline, 2010; 3: 317-332.

- El-Sayed MM, Maher ME, Eman AE, Ghareeb MA. Total phenolic contents and antioxdant activities of Ficus sycomorus and Azadirachta indica. Pharmacologyonline, 2009; 3: 590-602.

Ghareeb MA, Hussein AS, Hassan MFM, Laila AR, Mona AM, Amal MS. Antioxidant and cytotoxic activities of Tectona grandis Linn. leaves. Int J Phytopharmacol, 2014; 5:143-157.

Ghareeb MA, Hussein AS, Hassan MFM, Laila AR, Mona AM, Amal MS. Radical scavenging potential and cytotoxic activity of phenolic compounds from Tectona grandis (Linn.). Global J Pharmacol, 2013; 7: 486-497.

Ghareeb MA, Laila AR, Amal MS, Nadia SO, Mohamed SA, Maha AE, Asmaa SM. In vitro antimicrobial activity of five Egyptian plant species. J ApplPharm Sci, 2015a; 5: 045-049.

Ghareeb MA, Laila AR, Amal MS, Nadia SO, Maha AE, Asmaa SM. Cytotoxic screening of three Egyptian plants using brine shrimp lethality test. Int J Pharm Pharm Sci, 2015b; 7: 507-509.

Govindaraju K, Tamilselvan S. Silver nanoparticles by Solanum torvum and their promising antimicrobial activity. J Biopest, 2010; 3(1): 394-399.

Goyal PK, Jain R, Jain S, Sharma A. A Review on biological and phytochemical investigation of plant genus Callistimon.Asian Pac $\mathbf{J}$ Trop Biomed, 2012; S1906-S1909.

Haque A, Siddiqi MMA, Rahman AFMM, Chowdhury AMS, Hasan CM. Antimicrobial and cytotoxic activities of the crude extracts of Callistemon linearis. Int J Biosci, 2013; 3(3): 129-133.

Haque ME, Sultana A, Shibib BA, Islam MM. Antimicrobial, antioxidant and cytotoxic activities of Callistemon citrinus (Curtis) Skeels. Dhaka Univ J Pharm Sci, 2012; 11(1): 51-54.

Huq F, Misra LN. An alkenol and C-methylated flavones from Callistemon lanceolatus leaves. Planta Med, 1997; 63(4): 369-370.

Ipsen J, Feigi P. 1970. Bancroft's Introduction to Biostatistics. $2^{\text {nd }}$ ed., Harper and Row. New York 15.

Ismail EH, KhalilMMH, Al Seif FA, El-Magdoub F. Biosynthesis of gold nanoparticles using extract of Grape (Vitis Vinifera) leaves and seeds. Prog Nanotechnol Nanomater,2014; 3: 112.
Jamzad M., Kazembakloo A., Dadkhah-Tehrani A., Rostami F. Essential oil composition and antioxidant activity of hydromethanolic extract from the flowers, leaves and stems of Callistemon citrinus (Curtis) Skeels. Indian J Nat Prod Resour, 2014; 5(4): 308-312.

Jha AK, Prasad K, Kulkarni AR. Synthesis of $\mathrm{TiO}_{2}$ nanoparticles using microorganism. Colloid Surface B, 2009; 71: 226-229.

Kirthika P, Dheeba B, Sivakumar R, Sheik AS. Plant mediated synthesis and characterization of silver nanoparticles. Int $\mathbf{J}$ of Pharm Pharm Sci, 2014; 6(8): 304-310.

Krishna KVVS, Surendra G, Anjana M, Nagini KSKS. Phytochemical screening and antimicrobial activity of Callistemon citrinus (L.) leaves extracts. Int J PharmTech Res, 2012; 4(2): 700-704.

Kumar KS, Ganesan K, Rao PV. Antioxidant potential of solvent extracts of Kappaphycus alverezii (Doty). Edible seaweed. Food Chem, 2008; 107: 289-295.

Leela A, Vivekanandan M. Tapping the unexploited plant resources for the synthesis of silver nanoparticles. Afr J Biotechnol, 2008; 7: 3162-3165.

Mc Donell G, Russell AD. Antiseptics and disinfectants: activity, action, and resistance. Clin Microbiol Rev, 1999; 12 (1): 147-179.

Meyer BN, Ferrrigni NR, Putnam JE, Jacobsen LB, Nichols E, Mclaughlin JL. Brine shrimp: a convenient general bioassay for active plant constituents. Planta Med, 1982; 45, 31-34.

Mittal AK, Chisti Y, Banerjee UC. Synthesis of metallic nanoparticles using plant extract. Biotechnol Adv, 2013; 30: 346-356.

Pal S, Tak YK, Song JM. Does the antibacterial activity of silver nanoparticles depend on the shape of the nanoparticle? A study of the Gram-negative bacterium Escherichia coli. Appl Environ Microbiol,2007; 73:1712-1720.

Pattanayak M, Nayak PL. Green synthesis of gold nanoparticles using Elettaria cardamomum (ELAICHI) aqueous extract. World J Nano Sci Technol, 2013; 2: 01-05.

Ponarulselvam S, Panneerselvam C, Murugan K, Aarthi N, Kalimuthu K, Thangamani S. Asian Pac J Trop Biomed, 2012; 2(7): 574580.

Prabhu N, Divya T.R, Yamuna G. Synthesis of silver phyto nanoparticles and their antibacterial efficacy. Digest $\mathrm{J}$ Nanomater Biostruct, 2010; 5: 185-189.

Puranik N, Sohani S, Bakshi G. In vitro antioxidant and antigenotoxic potential of ethanolic extract of Callistemon citrinus flower. Int J Biol \& Pharm Res, 2014; 5(11): 824-829.

Rajakumar G, Gomathi T, Rahuman A, Thiruvengadam M, Mydhili G, Kim S-H, Lee T-J, Chung I-M. Biosynthesis and biomedical applications of gold nanoparticles using Eclipta prostrata leaf extract. Appl Sci, 2016; 6: 1-13.

Rao KJ, Paria S. Green synthesis of gold nanoparticles using aqueous Aegle marmelos leaf extract and their application for thiamine detection. RSC Adv, 2014; 4: 28645-28652.

Rashidipour M, Heydari R. Biosynthesis of silver nanoparticles using extract of olive leaf: synthesis and in vitro cytotoxic effect on MCF7 cells. J Nanostruct Chem, 2014; 4: 112.

Raut RW, Kolekar NS, Lakkakula JR, Mendhulkar VD, Kashid SB. Photosynthesis of silver nanoparticles using Gliricidia sepium (Jecq), Curr Nanosci 2009; 5: 117-122.

Roy K, Sarkar CK, Ghosh CK. Plant-mediated synthesis of silver nanoparticles using parsley (Petroselinum crispum) leaf extract: spectral analysis of the particles and antibacterial study. Appl Nanosci, 2015; 5: 945-951.

Shinde PR, Patil PS, Bairagi VA. Pharmacognostic, phytochemical properties and antibacterial activity of Callistemon citrinus viminalis leaves and stems. Int J Pharm Pharm Sci, 2012; 4(4): 406-408.

Shivakumar SP, Vidyasagar GM. Biosynthesis, characterization, and antidermatophytic activity of silver nanoparticles using Raamphal plant (Annona reticulata) aqueous leaves extract. Indian J Mater Sci, 2014; 1-5.

Shoeb HA, Hassan MFM, Laila AR, Mona AM, Amal MS, Mosad AG. Antioxidant and cytotoxic activities of Gmelina arborea ROXB.leaves. Br J Pharm Res, 2014; 4: 125-144. 
Siemieniec J, Kruk P. Synthesis of silver and gold nanoparticles using methods of green chemistry. Chemik, 2013; 67(10): 842-847.

Simon PDY, Okechukwu EC, Nchiwan NE. Larvicidal and phytochemical properties of Callistemon rigidus $\mathrm{R}$. Br. (Myrtaceae) leaf solvent extracts against three vector mosquitoes. J Vector Borne Dis, 2014; 51: 216-223.

Singh C, Baboota RK., Naik PK., Singh H. Biocompatible synthesis of silver and gold nanoparticles using leaf extract of Dalbergia sissoo. Adv Mat Lett, 2012; 3(4): 279-285.

Varma RS, Parthasarathy MR. Triterpenoids of Callistemon lanceolatus leaves. Phytochemistry, 1975; 14(7): 1675-1676.

Willner I, Baron R, Willner B. Growing metal nanoparticles by enzymes. J Adv Mater, 2006; 18: 1109-1120.

Wollenweber E, Wehde R, Dörr M, Lang G, Stevens JF. CMethyl-flavonoids from the leaf waxes of some Myrtaceae. Phytochemistry, 2000; 55(8): 965-970.

\section{How to cite this article:}

Saad AM, Abdel-Aleem AH, Ghareeb MA, Hamed MA, AbdelAziz MS, Hadad AH. In vitro antioxidant, antimicrobial and cytotoxic activities and green biosynthesis of silver \& gold nanoparticles using Callistemon citrinus leaf extract. J App Pharm Sci, 2017; 7 (06): 141-149. 